\title{
Asean Law And Economic Growth Asean
}

Nairobi 1)*, Debby Anggun Kenita ${ }^{2)}$, Fakultas Ekonomi dan Bisnis, Universitas Lampung

*E-mail corresponding author: nairobi@feb.unila.ac.id

Received: 22-03-2021;

Accepted: 21-04-2021;

Available online: 30-04-2021

Ecoplan Vol. 4 No. 1, April 2021, hlm 77-85.

\section{ISSN p: 2620-6102 e: $2615-5575$}

\begin{abstract}
Abstrak- Masyarakat Ekonomi ASEAN atau biasa disebut AEC (ASEAN Economics Community) tahun 2015 yang merupakan wujud kerjasama anatar negara-negara anggota ASEAN melalui integrasi sektor ekonomi dalam suatu pasar tunggal di kawasan Asia Tenggara. Hal ini juga menjadi jawaban atas pertanyaan investor tentang aksesibititas negara tujuan investasi termasuk salah satu yang dimaksud ialah kepastian hukum. Penelitian ini bertujun untuk menganalisis pengaruh penegakan hukum terhadap pertumbuhan ekonomi. Adanya peran pemerintah dalam penegakan hukum diharapkan mampu mendooroang pertumbuhan ekonomi suatu negara. Data yang digunakan alam penelitian ini antara lain pertumbuhan ekonomi, rule of law, voice and accountability, foreign direct investment, tenaga kerja, dan initial growth di 10 anggota ASEAN pada periode 2007-2018. Metode yang digunakan yaitu Random Effect Model. Hasil menunjukkan bahwa rule of law, foreign direct investment, tenaga kerja, dan initial growth berpengaruh signifikan dan positif terhadap pertumbuhan ekonomi di ASEAN, sedangkan voice and accountability sidak beprngarh signifikan terhadap pertumbuhan ekonomi ASEAN pada periode 2007-2018.
\end{abstract}

Abstract - The ASEAN Economic Community, commonly referred to as AEC (ASEAN Economic Community) in 2015, is a form of cooperation between ASEAN member countries by integrating the economic sector in a single market in the Southeast Asia region. This is also an answer to investors' questions regarding the accessibility of investment destination countries, including legal certainty. This study aims to analyze the effect of law enforcement on economic growth. The role of the government in law enforcement is expected to be able to support the economic development of a country. The data used in this study include economic growth, the rule of law, voice and accountability, foreign direct investment, employment, and the initial development of 10 ASEAN member countries for the 2007-2018 period. The method used is panel data regression and testing the significance of the model. The method used is the Random Effect Model. The results show that the rule of law, foreign direct investment, labor, and initial growth have a significant and positive effect on economic growth in ASEAN. In contrast, voice and accountability significantly impact ASEAN economic growth in the 2007-2018 period.

Keywords: ASEAN, Economic Growth, Random Effect Model, and the rule of law. 


\section{INTRODUCTION}

Increasing economic growth is not a matter that can be carried out easily for some countries in the world. Problems commonly experienced such as low quality of health, high levels of poverty, low life expectancy, and income disparities often occur in developing countries and underdeveloped/poor countries, where it will also have an impact on the economic growth of each country (Syadullah \& Wibowo, 2015).

Countries in Southeast Asia have stable economies and have economic resilience in the face of challenges from the global environment. Southeast Asian countries who are members of the Association of Southeast Asian Nations (ASEAN) are also involved in promoting economic growth, reducing poverty, and improving people's lives. ASEAN's vision until 2020 is to strengthen the economy through economic strategies that promote sustainable growth among countries within a region (ASEAN \& Forum, 2020).

2015 saw the realization of the AEC (ASEAN Economic Community), which is a form of cooperation between ASEAN member countries through the integration of the economic sector in a single market in the Southeast Asia region. This is also an answer to investors' questions regarding the accessibility of investment destination countries, including legal certainty (ASEAN \& Forum, 2020).

Activities in the economic field require freedom in carrying out its activities, freedom to create and develop oneself according to their knowledge and will so that to obtain large profits with small capital can be achieved easily, but the law has a nature that limits human behavior to commit excessive actions. bad impact on the economy. Traditional theorists agree that a good legal system has been associated with welldefined property rights, reduced transaction costs, increased investment, and economic growth (Li \& Li, 2013).

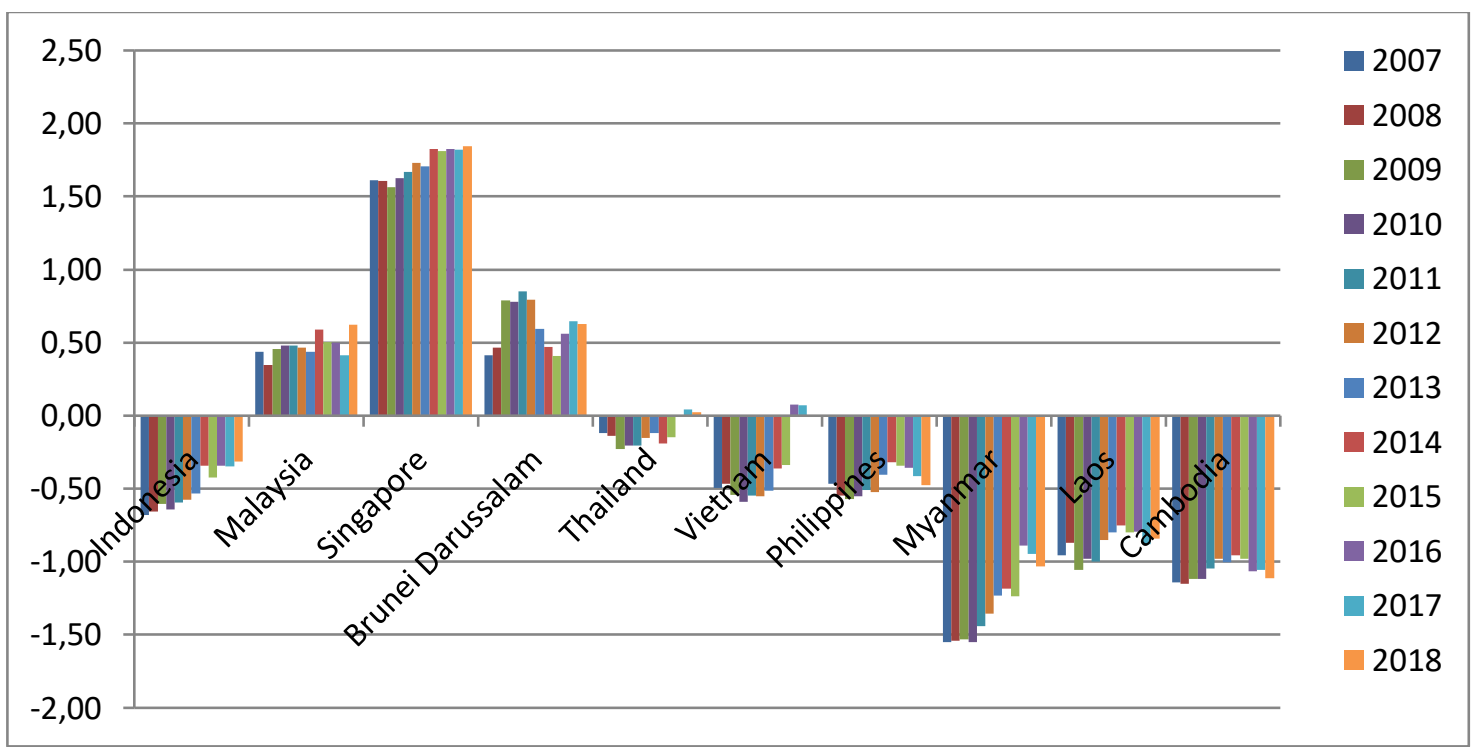

Source: World Bank, 2020

Figure 1. Development of the ASEAN Rule of Law for the 2007-2018 Period

Based on Figure 1, the rule of law index in each country is increasing, except for Brunei Darussalam. On average, in the 2007-2018 period, the highest level of compliance and law enforcement occurred in Singapore with 1,72 points, followed by Brunei Darussalam (0,62 points), Malaysia (0,48 points), and Thailand (-0,12 points). Meanwhile, the lowest level of compliance and law enforcement occurred in Myanmar with $-1,29$ points, followed by Cambodia (-1,06 points), Laos (-0,88 points), and Indonesia (-0,50 points).

According to Haggarrd (2010), there is a close correlation between law enforcement and economic growth, efficient transactions in an ideal market will occur when supported by the rule of law implemented by a government with good governance. The existence of political and legal institutions that carry out supervisory and balance functions (Checks on Government) such as the government, parliament, and independent courts allows control and prevention of various forms of abuse of power, both from political and legal institutions that inhibit economic growth.

According to Syadullah \& Wibowo (2015), to measure the welfare of a country not only in terms of GDP but also through aspects of law enforcement and democracy. A good legal system has been associated with well-defined property rights, reduced transaction costs, increased investment, and economic growth (Man Li and Lut Li, 2013), but based on data on economic growth and law enforcement in ASEAN in 2007-2018 There is a gap between existing theory and data, where some countries with high levels of 
law enforcement, actually show low levels of economic growth. This raises the question, "what is the influence of law enforcement on economic growth in the 10 ASEAN countries in the 2007-2018 period?". Using Levine \& Renelt's (1992) growth model, is there the rule of law, FDI.

The Rule of Law has a significant positive effect on the dependent variable, namely economic growth. These results mean that if there is an increase in community compliance in obeying regulations and enforcing the law, it will increase the rate of economic growth (Syadullah \& Wibowo, 2015).

Haggarrd (2010) also argues that the rule of law has a significant effect on economic growth in developed countries. The rule of law is an important indicator in creating good governance because the rule of law can limit government authority so that it does not become a corrupt government.

A government that obeys the law can carry out its duties, powers, and responsibilities. The rule of law can guarantee that the government runs cleanly and well so that in the end, it is expected to have a broad impact on economic progress and increase the rate of economic growth. Also, the rule of law is important for improving the welfare of a country because the rule of law does not only guarantee and protect people's rights to work, the right to establish a business, and the right to live a decent life. The rule of law also guarantees legal protection for property, business capital, and legal certainty in making investments. But in essence, the rule of law is more aimed at producing the basic pillars of an economy that is resilient to crises and capable of increasing the rate of economic growth.

$\mathrm{Xu}$ (2012) this factor is procedural, apart from the substantive content of the law, it is also very difficult to operationalize for empirical research, although it is expected in some investor guides. Researchers are increasingly studying the effects of government regulations on economic development. The new institutional economy may be depicted as positing the ideology of Laissez-Faire, in which the main role of government is to create property rights and enforce contracts and then get out of the way of the market. Coasean's theory calls for government intervention wherever it reduces transaction costs under a no-government intervention. Free markets may not promote development efficiency for many reasons, including information asymmetry. An empirical analysis is needed to understand the impact of government regulation. The most studied area of public regulation is securities law. A larger and more liquid securities market is contributing to economic growth.

Ozpolat et al. (2016) stated in their research that the rule of law index, the corruption control index, and the voting and accountability index are positively correlated with the GDP of high-income countries. Other studies, Roxas et al. (2012) dan Sihag (2007), also convey the same thing, where according to him, the rule of law index has a significant positive effect on economic growth. Increasing public compliance in obeying regulations and enforcing laws will increase the rate of economic growth. A government that obeys the law can carry out its duties, powers, and responsibilities. The rule of law can guarantee that the government runs cleanly and well so that in the end, it is expected to have a broad impact on economic progress and increase the rate of economic growth.

Resnick, D., and Birner (2006) reveal that governance indicators (political stability and the rule of law) have a positive relationship with economic growth but have given mixed results in terms of poverty alleviation. Huynh \& Jacho-Chávez (2009) stated that the indicators of voice and accountability, political stability, and the rule of law significantly affect economic growth. Haggard \& Tiede (2011) also states that the rule of law has a significant effect on economic growth in developed countries.

Febryani (2017) mentions the fact that economic growth in ASEAN countries is still dominated by public consumption. Theoretically, economic growth that is supported by consumption will not lead to sustainable economic growth, while sustaining economic growth is supported by investment. This is because an investment is considered a factor that will increase the productivity of a country and increase the country's economic growth.

In the economic market, some problems are not predicted by classical economic theory where there are economists who prioritize individual behavior so that what happens is moral hazard and free-rider behavior caused by the desire of individuals to maximize profits and not thinking about the impact experienced by other economic actors. To reduce the risk of free riders as well as the occurrence of moral hazard and asymmetric information, it is necessary to have strict and firm rules of the game that regulate individual behavior in economic transactions, namely in the form of the rule of law.

They were using the model proposed by Levine \& Renelt (1992), where I was chosen based on the theory of economic growth, namely the Foreign Direct Investment variable or commonly referred to as direct investment as the initial capital and also the labor force variable and initial growth variables. $M$ is the focus variable in this study, namely the rule of law, while $\mathrm{Z}$ is another variable in research related to growth that can also explain economic growth, namely the variable voice and accountability as a measure of voice and accountability. The variables mentioned in the previous statement were selected based on empirical studies related to this research. 
Economic factors in research such as FDI, labor force, voice and accountability, and initial growth variables are included as variables in this study which represent all research conditions in economic growth, namely in terms of capital stock in the form of foreign direct investment as a direct investment leading to capital stock accumulation. , labor.

Voice and accountability variables are used as variables to measure democracy, the level of participation, and freedom of society in making policy decisions to be made by a country, because according to Stiglitz (2015), measuring welfare can also be done with indicators of democracy as an environmental instrument. Voice and accountability are also used based on an empirical study conducted by (Ozpolat et al., 2016). This research was conducted to analyze the effect of the legal influence that occurs in ASEAN on economic growth so that it can be used as a guide by the state in the law enforcement process to maintain the country's economic stability.

\section{LITERATURE REVIEW}

\section{Law Enforcement Theory}

Law enforcement, according to Akhmaddhian (2016), is a process to make legal desires come true. The legal desires referred to here are those of the legislative body formulated in these legal regulations. The formulation of the thoughts of lawmakers, as outlined in legal regulations, also determines how law enforcement is carried out. Thus, in turn, the law enforcement process culminates in its implementation by the law enforcement officials themselves. From this situation, with an extreme tone, it can be said that the success or failure of law enforcers in carrying out their duties has started since the legal regulations that had to be carried out were made.

The rule of law is widely used and is often associated with state development efforts - no agreed definition agreement. The definitions below, articulated by the Secretary-General of the United Nations in a report to the Security Council in 2004, provide the basis for the rule of law indicators. The United Nations states that the rule of law itself is a measure of the extent to which a person obeys the rules of society and enforces the law. The rule of law can guarantee that the government runs cleanly and well so that in the end, it is expected to have a broad impact on economic progress and increase the rate of economic growth (Matsuo, 2008).

The rule of law is also important for improving the welfare of a country because the rule of law not only guarantees and protects people's rights to work, the right to establish a business, and the right to live properly. The rule of law also guarantees legal protection for property, business capital, and legal certainty in making investments. But in essence, the rule of law is more aimed at producing the basic pillars of an economy that is resilient to crises and capable of increasing the rate of economic growth (Matsuo, 2008).

\section{Economic Growth Theory}

Economic growth is a very important indicator for assessing the performance of an economy, especially for analyzing the results of the economic development process in a country or region. The economy is said to experience growth if the production of goods and services increases from the previous year (Mankiw, 2019).

Economic growth shows the extent to which economic activity can generate additional income or social welfare in a certain period which can illustrate that the economy of the country or region is developing well. Every developing country wants to carry out development in all fields and is expected to achieve high economic growth, become a developed country, and be able to realize the goal of prospering society and even distribution of income in the context of realizing justice (Krugman \& Wells, 2018).

Mankiw (2019), in general, the process of economic growth is influenced by two kinds of factors, namely economic and non-economic factors. The economic growth of a country is highly dependent on its natural resources, human resources, capital, business, technology, and so on. These are all economic factors. But economic growth is not possible as long as the social and cultural institutions, political and security conditions, and moral values in a nation are not supportive. In other words, without the support of such non-economic factors properly, economic growth may not materialize.

\section{Voice and accountability}

From an institutional point of view, other factors in government are also related to economic growth that describes the welfare and prosperity of a country. Stiglitz (2015) argues that the participation of public opinion about government decisions in making policies, but opinion polls consistently show that there is a big difference between what most voters want and what the political system provides. Voting and participating in voting for government decisions, as well as freedom of expression, freedom of association, 
accountability, captures perceptions about the extent to which citizens can, and free media. Maune (2017) says that voice and accountability have a positive impact on GDP.

\section{Relationship Between Law Enforcement and Economic Growth}

There is a close correlation between the law enforcement system and economic growth; efficient transactions in an ideal market will occur when supported by the rule of law implemented by a government with good governance (Fickar, 2015). Haggarrd (2010) suggests four components of the rule of law that can support economic growth, including First, individual security (Security of Person), which means that economic actors must be free from all forms of obstacles, disturbances, and threats, both physical and/or psychological from any party in conducting transactions. Second, recognition and appreciation of the right to property and the right to freedom of contract (Property and Contracting Rights). These two rights can provide incentives for people to invest and trade. In this way, he will encourage economic growth as long as the state, through its legal institutions, can respect and enforce these civil rights. The right to property and the right to freedom of contract are human rights. However, its protection and promotion by the state do not appear to be sufficiently convincing to the market.

Third, the presence of political and legal institutions that carry out the function of supervision and balance (Checks on Government), such as the government, parliament, and independent courts. This check and balance function enables the prevention and control of various forms of abuse of power, both from political and legal institutions that impede economic growth. Fourth, consistency in the prevention and eradication of corruption (Corruption and the Rule of Law).

The four components described by Haggard are interdependent and complement each other to form a complex system of the rule of law as one of the determinants of national economic growth. We encounter these four components but have not yet formed a rule of law complex, the parts of which are aware of the complementary nature and depend on each other in coordination for growth and equitable distribution of welfare.

\section{METHOD}

This study uses panel data from 10 countries in ASEAN due to Timor Leste being a member of ASEAN in 2011 and the research year from 2007-2018, data obtained from World Bank publications (World Development Indicators and Worldwide Governance Indicators).

The dependent variable in this study is economic growth, while the independent variable consists of the rule of law, voice and accountability, Foreign Direct Investment, labor force, and initial growth. The economic growth model used adopts the growth model of Levine \& Renelt (1992), namely:

$$
\mathrm{Y}=\beta \mathrm{iI}+\beta \mathrm{mM}+\beta \mathrm{zZ}+\mu(1)
$$

Where $\mathrm{Y}$ is economic growth, variable $\mathrm{I}$ is a variable that must exist theoretically in the growth model, $\mathrm{M}$ is the independent variable that is the researcher's interest, $\mathrm{Z}$ is another variable as a compliment. In this study, I am FDI, labor force, and initial growth. The variable $\mathrm{M}$ is the rule of law variable, and $\mathrm{Z}$ is the voice and accountability variable. Then the structural equation is formed as follows:

$$
\mathrm{EG}_{\mathrm{it}}=\beta_{0}+\beta_{1} \mathrm{RL}_{\mathrm{it}}+\beta_{2} \mathrm{FDI}_{\mathrm{it}}+\beta_{3} \mathrm{LF}_{\mathrm{it}}+\beta_{4} \mathrm{VA}_{\mathrm{it}}+\beta_{5} \mathrm{IG}_{\mathrm{it}}+\varepsilon_{\mathrm{it}}
$$

Selection of the best model for panel data uses three methods (Baltagi, 2008), namely: Selection of the best model in the panel data method uses three methods(Beckett, 1975)as follows: a) Pooled Least Square (PLS) is the simplest estimate in panel data testing, which combines cross-section and time-series data. The test only uses the Ordinary Least Square without paying attention to individual dimensions (crosssection) and time dimensions (time series); b) Fixed Effect Model (FEM) in this approach assumes that the intercept between the cross-section dimensions is different but the slope of the time series dimensions remains the same; c) Random Effect (REM) which tends to see changes between cross-sections and between time series. The REM method is used to perfect the FEM model.

To determine the best model that can be used in analyzing and predicting three stages of testing, namely the Chow test to choose the best model between PLS and FEM, the Hausman test to choose the best model between FEM and REM, and the LM test to choose the best model between PLS and REM (Beckett, 1975). 


\section{RESULTS AND DISCUSSION}

Table 1. Results of Panel Data Regression for Economic Growth Bound Variables

\begin{tabular}{cc}
\hline Variable & REM \\
\hline Constant & 10,4057 \\
$(0,0004) *$ \\
\hline Rule of Law (RL) & 2,2389 \\
& $(0,0000) *$ \\
\hline Foreign Direct Investment (FDI) & 0,2829 \\
Labor Force (LF) & $(0,0000) *$ \\
\hline \multirow{2}{*}{ Voice and Accountability (VA) } & 0,1275 \\
\hline \multirow{2}{*}{ Initial Growth (IG) } & $(0,0048) *$ \\
\hline \multirow{2}{*}{ Chow test } & 0,2638 \\
& $-0,5092$ \\
\hline \multirow{2}{*}{ Hausman Test } & 0,275 \\
& $(0,0005) *$ \\
\hline \multirow{2}{*}{ Lagrange Multiplier (LM) Test } & 1,2739 \\
\end{tabular}

Source: Eviews 9.0 output

Information: $*$ ) significant at $\alpha=5 \%$ and $* *$ ) significant at $\alpha=10 \%$

Based on Table 1, using three approaches, it was found that the chow test resulted in a better FEM method than CEM, while in the Hausman test, the REM method was better than REM, and the LM test showed that the CEM method was better than REM. However, according to Gujarati \& Porter (2013), if I (the number of cross-section units) is greater than $t$ (the number of periods) then, the best and efficient model for analyzing the data of this research is the Random Effect Model (REM).

$\mathrm{EG}_{\mathrm{it}}=10,41-2,24 \mathrm{RL}_{\mathrm{it}} *+0,28 \mathrm{FDI}_{\mathrm{it}} *-0,13 \mathrm{LF}_{\mathrm{it}} *-0,26 \mathrm{VA}_{\mathrm{it}}+0,27 \mathrm{G}_{\mathrm{it}} *$

$\mathrm{R}^{2}=0,51$

Statistics $=23,46$

Note: *) Significant at $95 \%$ confidence level

**) Significant at $90 \%$ confidence level

The constant value is 10.41 , which indicates that when all independent variables are zero, the economic growth will be 10.41 percent. The rule of law, Foreign Direct Investment, labor force, and initial growth have a significant and positive effect on economic growth, while voice and accountability do not have a significant effect on economic growth.

\section{Classic Assumption Testing}

Based on the results of the classical assumption testing that has been done, it shows that the research model has passed the classical assumption test.

\section{Analysis of Calculation Results and Discussion}

The rule of law has a positive and significant effect on economic growth. The results are by neoclassical economic theory, where economic growth and law are things that cannot be combined because the law has a limiting nature. This is due to the factor of law enforcement costs; the inefficiency factor in the law enforcement process of a country also influences growth so that an efficient law enforcement process is needed to create good economic growth.

The rule of law is an important indicator in creating good governance. Because the rule of law can limit the government's authority so that it does not become a corrupt government, a government that obeys the law can carry out its work, authority, and responsibility. The rule of law guarantees that the government runs cleanly and well so that it has a broad impact on economic progress and increases the rate of economic growth. 
Also, the rule of law plays an important role in improving the welfare of a country because the rule of law not only guarantees and protects people's rights to work, the right to establish a business, and the right to live properly. The rule of law also guarantees legal protection for property, business capital, and legal certainty in making investments.

A good rule of law in a country will reduce the level of investment uncertainty and increase the confidence of investors in investing so that it can encourage business activities and, in turn, will increase the economic growth of a country. Conversely, if the rule of law of a country is bad, the transaction costs will definitely increase, and private companies will operate on a small scale, and they may even commit acts of corruption or criminal acts to run their business. This, of course, will reduce the economic growth of a country.

In essence, the rule of law aims to produce the basic pillars of an economy that is resilient to crises and can increase the rate of economic growth. Ozpolat et al. (2016) and Roxas et al. (2012) state that law enforcement has a positive and significant effect on economic growth.

Foreign Direct Investment has a positive and significant effect on economic growth. The results are following the economic growth theory of Levine \& Renelt (1992), which states that there is an increase in economic growth due to an increase in the supply of inputs, one of which is capital (Ma'ruf \& Wihastuti, 2008). Dkhili \& Dhiab (2018), Alzaidy et al. (2017), Febryani (2017), Behname (2012), and Wibisono (2005) Foreign Direct Investment in a country can encourage the country's economic growth.

The labor force has a positive and significant effect on economic growth. A larger number of workers means an increase in the level of production, while a larger population growth means a larger size of the domestic market. However, it is questionable whether it is true that the rapid population growth rate will have a positive or negative impact on its economic development. Nawaz (2015), Wicaksono (2014), and Febryani (2017) state that the workforce has a positive influence on economic growth.

Voice and Accountability do not affect economic growth. The voting theory by Buchanan and Tullock states that there is a direct relationship between the desire for voting efficiency and costs, where we want efficient voting, namely satisfying everyone, then the cost required is greater, on the contrary, if the voting results are only to satisfy one person only. (king or dictator), the voting costs issued are also very low (Man Li \& Li, 2013). These results are in line with previous research conducted by Moricz \& Sjöholm (2014) and Wibowo (2013), which states that no matter how much citizen participation in choosing parties and leaders, as well as freedom of opinion, freedom of association, and freedom to determine public policy, it does not affect economic growth.

Initial growth has a positive and significant effect on economic growth. According to Levine \& Renelt (1992), initial growth is a component that affects economic growth in a country. Therefore, in analyzing economic growth in a region, the core growth must be included in the research model. the regression result is positive, meaning that there is a convergence of economic growth in that country. These results are in line with previous research conducted by Nawaz (2015) and Klomp \& de Haan (2009), who found that the GDP per capita lag had an effect on economic growth.

\section{CONCLUSIONS AND SUGGESTIONS}

Based on the results of research which shows that the high value of the rule of law has an impact on economic growth in ASEAN, the higher the rule of law explains that there is a high level of legal compliance. From the results and discussion of the rule of law, foreign investment, labor force, and initial growth have a positive and significant effect on economic growth, while Voice and Accountability have no effect on economic growth.

The government further reminds and realizes an efficient law enforcement process to create harmony and balance in the economy of the people who then feel safe and protected by their rights, improve the quality of their governmental institutions by improving the aspects of law enforcement that are efficient, effective. Freedom of opinion, so that it can have an impact on increasing the country's economic growth.

\section{REFERENCE}

Akhmaddhian, S. (2016). Penegakan Hukum Lingkungan dan Pengaruhnya terhadap Pertumbuhan Ekonomi di Indonesia (Studi Kebakaran Hutan Tahun 2015). UNIFIKASI : Jurnal Ilmu Hukum, 3(1), 1-35. https://doi.org/10.25134/unifikasi.v3i1.404

Alzaidy, G., Naseem, M., Niaz, B., \& Lacheheb, Z. (2017). The Impact of Foreign-direct Investment on Economic Growth in Malaysia: The Role of Financial Development. International Journal of Economics and Financial Issues, 7(3), 382-388.

ASEAN, R., \& Forum, W. E. (2020). ASEAN Services Integration Report. ASEAN Report. 
Baltagi, B. H. (2005). Econometric Analysis of Panel Data. In John Wiley \& Sons Ltd (3th ed., Vol. 5, Issue 7). John Wiley \& Sons Ltd. https://doi.org/10.3109/00498257509056115

Behname, M. (2012). Foreign Direct Investment and Economic Growth: Evidence from Sothern Asia. Atlantic Review of Economics, 2. https://doi.org/10.1504/AAJFA.2015.073487

Dkhili, H., \& Dhiab, L. (2018). The Relationship between Economic Freedom and FDI versus Economic Growth: Evidence from the GCC Countries. Journal of Risk and Financial Management, 11(4), 81. https://doi.org/10.3390/jrfm11040081

Febryani, T. (2017). Determinan Pertumbuhan Ekonomi di 4 Negara ASEAN. Jurnal Ilmu Ekonomi Terapan, 2(1), 10-20. https://doi.org/10.20473/jiet.v2i1.5501

Fickar, A. (2015). Hukum dan Pertumbuhan Ekonomi. Jurnal Hukum PRIORIS, 5(1).

Gujarati, D. N., \& Porter, D. . (2009). Single-equation regression models. In Introductory Econometrics: A Practical Approach (5th ed.). Douglas Reiner.

Haggard, S., \& Tiede, L. (2011). The Rule of Law and Economic Growth: Where are We? World Development, 39(5), 673-685. https://doi.org/10.1016/j.worlddev.2010.10.007

Haggarrd, S. (2010). The Rule of Law and Economic Growth: Where Are We? Conference on Measuring the Rule of Law, 1-43.

Huynh, K. P., \& Jacho-Chávez, D. T. (2009). Growth and governance: A nonparametric analysis. Journal of Comparative Economics, 37(1), 121-143. https://doi.org/10.1016/j.jce.2008.08.003

Klomp, J., \& de Haan, J. (2009). Political institutions and economic volatility. European Journal of Political Economy, 25(3), 311-326. https://doi.org/10.1016/j.ejpoleco.2009.02.006

Krugman, P., \& Wells, R. (2018). Macroeconomics (Fifth Edit). Worth Publishers.

Levine, R., \& Renelt, D. (1992). A Sensitivity Analysis of Cross-Country Growth Regressions. American Economic Review, 82(4), 942-963. https://doi.org/10.2307/2117352

Li, R. Y. M., \& Li, Y. L. (2013). Is there a positive relationship between law and economic growth? A paradox in China. Asian Social Science, 9(9), 19-30. https://doi.org/10.5539/ass.v9n9p19

Ma'ruf, A., \& Wihastuti, L. (2008). PERTUMBUHAN EKONOMI INDONESIA: Determinan dan Prospeknya. Jurnal Ekonomi \& Studi Pembangunan, 9(1), 44-55. https://doi.org/10.18196/jesp.9.1.1526

Man Li, R. Y., \& Li, Y. L. (2013). Is there a positive relationship between law and economic growth? A paradox in China. Asian Social Science, 9(9), 19-30. https://doi.org/10.5539/ass.v9n9p19

Mankiw, N. G. (2019). Macroeconomis, 10th Edition. In Worth Publishers.

Matsuo, H. (2008). The Rule of Law and Economic Development: A Cause or a Result? Center for Asian Legal Exchange, 59-70. https://doi.org/10.1002/9780470693650.ch32

Maune, A. (2017). The strength of sound corporate governance on economic growth in an emerging market context. International Journal of Economics and Financial Issues, 7(5), 6.

Moricz, S., \& Sjöholm, F. (2014). The Effect of Elections on Economic Growth: Results from a Natural Experiment in Indonesia. IFN Working Paper, 1023.

Nawaz, S. (2015). Growth effects of institutions: A disaggregated analysis. Economic Modelling, 45, 118126. https://doi.org/10.1016/j.econmod.2014.11.017

Ozpolat, A., Guven, G. G., Ozsoy, F. N., \& Bahar, A. (2016). Does Rule of Law Affect Economic Growth Positively? Research in World Economy, 7(1). https://doi.org/10.5430/rwe.v7n1p107

Resnick, D. and Birner, R. (2006). Does good governance contribute to Pro-Poor Growth?: A review of the evidence from cross-country studies Development Strategy and Governance. International Food 
Policy Research Institute, 12, 1-22.

Roxas, B., Chadee, D., \& Erwee, R. (2012). Effects of rule of law on firm performance in South Africa. European Business Review, 24(5), 478-492. https://doi.org/10.1108/09555341211254544

Sihag, B. S. (2007). Empirical studies on institutions, governance and economic growth: A review. Humanomics, 23(4), 204-220. https://doi.org/10.1108/08288660710834694

Stiglitz, J. E. (2015). The Price of Inequality: How Today’s Divided Society Endangers Our Future. Sustainable Humanity, Sustainable Nature: Our Responsibility, 1-21. https://doi.org/10.1080/09538259.2015.1067028

Syadullah, M., \& Wibowo, T. (2015). Governance and Tax Revenue in Asean Countries. Journal of Social and Development Sciences, 6(2), 76-88. https://doi.org/10.22610/jsds.v6i2.845

Wibisono, Y. (2005). Sumber-Sumber Pertumbuhan Ekonomi Regional: Studi Empiris Antar Propinsi di Indonesia, 1984-2000. In Jurnal Ekonomi dan Pembangunan Indonesia (Vol. 5, Issue 2, pp. 91-120). https://doi.org/10.21002/jepi.v5i2.137

Wibowo, E. (2013). Analisis Pengaruh Kualitas Pemerintahan Terhadap Pertumbuhan Ekonomi di ASEAN. Jurnal Ilmiah FEB Universitas Brawijaya, 1-14.

Wicaksono, M. N. (2014). Analisis Pengaruh Indeks Pembangunan Manusia, Angkatan Kerja, dan Belanja Modal Daerah terhadap Peningkatan PDRB Provinsi di Indonesia Tahun 2008-2012. Jurnal Ilmiah Mahasiswa FEB Universitas Brawijaya, 3(1).

Xu, G. (2012). Law and China's Economic Growth. The Dovenschmidt Quarterly, 1, 3-15. 